\title{
Teaching for Democracy in Nigeria: A Paradigm Shift
}

\author{
Donald Bette Enu ${ }^{1} \&$ Maxwell Borjor Eba ${ }^{2}$ \\ ${ }^{1}$ Department of Curriculum and Teaching, University of Calabar, Nigeria \\ ${ }^{2}$ Department of History and International Studies, University of Calabar, Nigeria \\ Correspondence: Donald Bette Enu, Department of Curriculum \& Teaching, University of Calabar, Nigeria. Tel: \\ 234-803-577-3024. E-mail: Bette2004@Yahoo.com
}

Received: January 25, 2014 Accepted: March 13, 2014 Online Published: May 29, 2014

doi:10.5539/hes.v4n3p64 URL: http://dx.doi.org/10.5539/hes.v4n3p64

\begin{abstract}
In this qualitative study, the authors addresses the complexities of the Nigerian Social Studies teaching context taking into cognizance the pervasive and lecture-based pedagogical process centered on rote learning and memorization. Democracy being a globally enthroned system of government can only endure when the citizens are actively involved by making input into the system of governance. Nigerian educators, particularly Social Studies educators, must rethink their teaching practices that will produce responsible democratic citizens. To achieve this, there is need to guide a transition in the teaching approach from rote learning to critical thinking. This paper therefore advocates for a restructuring of both the curriculum and instructional approach that will give Nigerian students the desired disposition to think for themselves so as to become good citizens in a sustainable democracy.
\end{abstract}

Keywords: teaching, democracy, citizens, curriculum, critical thinking

\section{Introduction and Background}

Nigeria is described by Petters (1997) as the largest concentration of African people, the most luminous concentration of black talents anywhere in the world, by far is the most bountifully endowed nation in the continent of Africa. Nigeria like America's statue of liberty, has been the beacon of hope and succor to the oppressed and displaced people of Africa. Nigeria is a creation of British political and military diplomacy, and so by 1898 , British military power had been firmly established in Nigeria. Almost all the conquered communities were different in race, language, culture and political organization. And so people from different backgrounds and with different world views were coerced to form a common group.

Northern Nigeria which is predominantly Muslim, had been under the influence of Islamic culture for a long time and had very little in common with Yoruba, Igbo, Ijaw, Efik, Ibibio and other ethnic minorities of the south. The British government, fully aware of this, convened the Selborne Committee on amalgamation which recommended an amalgamation completed in 1914 (Ubi, 2000). The three regions of Nigeria (North, South and East) struggled to work together as a federation. Till date, the struggle to attain a true federal system is still a big challenge.

From 1951 up to independence in 1960, Nigerian leaders negotiated for a federal constitution based on a parliamentary system of government. Shortly after independence, the parliamentary system of government failed as the entire country was plunged into a civil war (Biafran war) which was fought with deep bitterness and vengeance. Between 1979 and 1983, a second attempt at democratization was made adopting the American presidential system. This attempt was prematurely terminated by the military intervention of General Mohammadu Buhari.

The political struggle in Nigeria produced eleven (11) power changes between 1960 and 1993 on an average power change of every three years. Of the eleven (11), only three, with a cumulative life span of 9 years were democratically elected. Nigeria's transition from an autocratic military regime to a democratically elected civilian administration in May 1999 marked an important milestone in the political history of the country. This transition ended 16 straight years of authoritarian rule under several military heads of state (Gana \& Omelle, 2003).

In 53 years of Nigeria as a nation, it is only from 1999 to date that the country has operated a sustained 
democratic government. The nation's democratic culture is gradually being developed and in 2011, the nation's electoral body was able to midwife what was declared the most transparent election to date. That election produced President Goodluck Jonathan.

Given the history of Nigeria and in realization of the need to adopt global democratic best practices, it has become quite urgent to develop and support democratic values and habits of mind in schools. The central question of this study now for educators, especially for Social Studies educators in Nigeria, is: How do we teach Nigerian students to think for themselves so that they will be good citizens in a sustainable democracy?

\section{Conceptual Review: Teaching for Democracy}

What does it mean to educate for democracy? What is the mission of Nigerian schools in terms of providing democratic education? Every school should have a vision for students by making them responsible citizens. This vision according to Wood (1990) should give the students a sense of community that prepares them to make connections with the world. To corroborate this, NCSS (2010) noted that an understanding of civic ideals and practices is critical to full participation in society and is also an essential component of education for citizenship, which is the central purpose of Social Studies. It furthered that learning how to apply civic ideals as part of citizens' action is essential to the exercise of democratic freedoms and the pursuit of the common good. Schools should therefore be seen as laboratories where democracy is experienced, not museums where it is just observed. Social Studies educators should not only be concerned with verbally promoting the concept of Social Studies as education for democratic citizenship, and do not practice it in their classroom, but however, Social Studies teacher education programme should be considered as an apprenticeship in building democratic culture (Metzger \& Marker, 1992).

It is important to reiterate here that democracy is a fragile system of living together. The knowledge, character and skills citizens need to sustain it do not emerge without a well-tailored education programme. Democracy requires that we educate students on the fundamentals of democratic survival and citizen's requirement of great character and civility. This goes with the ability to reason in principled ways, i.e., the possession of a deep appreciation of democratic values such as liberty, the common good, justice, and equity. Most importantly, the ability to think critically, to resolve disputes in non-violent ways, to stay informed on critical public policy issues and disposition to insist on the promotion of people's rights. Not forgetting the development of cooperative way of living, the ability to tolerate religious and political views different from one's own, and to insist on the expression of those views (Gana \& Omelle, 2003). From the above, there is one recognized challenge: teachers and schools must necessarily have to do much to facilitate the acquisition of sustained democratic skills. Certain questions need be asked: are Nigerian teachers really teaching students in ways that prepare them to be truly democratic? Is the school curriculum properly equipped with what it takes to sustain a democracy?

The nation's current educational system was patterned after the nineteenth century British model. It was lecture-based, about the three R's, and focused on teaching for memorization and rote learning. This system largely persists. This is not an educational approach that provides learners with opportunities for critical thinking or creativity. It does not encourage questioning or analysis. Colonial masters and dictators do not tolerate questioning and analysis. But higher level thinking skills are essential for building and sustaining a democracy. Nigerian educators in general, and in particular Nigerian Social Studies Educators must re-think their practices in relation to the demands of democratic citizenship. That is why Blake, Smith and Standish (1998) stated in Teaching for Democracy in Higher Education that:

Democracy is founded on faith in the power of "pooled and cooperative experience". Through democratic, open relationships, as opposed to autocratic and authoritarian ones, however benign, we learn from and within one another. We can know things in this way, in combination with one another that we cannot know alone. Unless democratic habits of thought and action are part of the fiber of a people, Dewey writes, political democracy is insecure. (p. 68)

To support the need for a sound democratic education, Dewey (1941) noted that "to subject the mind to an outside and ready-made material is a denial of the ideal of democracy, which roots itself ultimately in the principle of moral, self-directing individuality".

However, as observed by a Russian Philosopher lecturer, not everybody can become critical Stephen (2003). According to him, if everyone starts criticizing the society, there will be trouble. We are not against this idea, the philosopher stated. But the role of education is to develop and to encourage students' critiques, to express their ideas, and skillfully and constructively criticize and analyze.

Even though many countries throughout history are being governed by elite men and women who make laws and 
legal judgments with little input from their citizens, the founders of democratic nations according to Portelli and Solomon (2001) believed in creating a government where the "common man" could have a voice in politics. And for such an approach to work, citizens must become aware, knowledgeable and active in their communities and nations. True democratic citizenship requires more than voting for representatives. It requires using one's own mind, voice and actions. Indeed Nigeria is one of the worst case scenarios in respect of meeting these democratic requirements. The citizens are neither given any opportunity by the rulers to make any input nor are they treated as having any democratic right conferred on them, in spite of the constitution.

Democracies all over are established on the belief that people should be free, should have choices and opportunities, and should work together to make each other's lives better. To maintain our democratic society, Nigerian teachers must start teaching students to be good citizens; they should go beyond teaching them to obey the laws of the land. Teachers must teach them about how their freedoms began and how they are maintained. Students must be taught to understand the fact that they can make a difference and that if they do not become involved democratic citizens, they risk losing their freedom. To demonstrate this, Stephen (2003) quotes a black South African female lecturer:

I grew up in the world of being timid, speaking when you are spoken to, being told "do this" and if you have not been told, you don't do it. So what I try to push into my students' behavior is that they query things, ask questions, that's why sometime I say something totally controversial because I am shocking them back into life.

However, the erosion of democratic values is not limited to Nigeria alone, even established democracies suffer the downward slope in terms of active participation of the young ones. This is evident in Kahne and Westheimier (2003) revelation that in America, the numbers that chronicle declining civic engagement are becoming increasingly familiar. That $25 \%$ fewer citizens go to the polls today than in the 1960 's, and the largest declines are among young people. Political participation they furthered, such as working for political party is at a 40 year low.

Democratic culture needs to be entrenched and promoted among citizens, especially through the formal school curriculum. On the strength of this, Kahne and Westheimer (2003) suggested that young people need to be taught to make democracy work, to engage civically, socially, and politically. At the same time that lobbyists are spending hundreds of millions of dollars, many ordinary citizens are passive and apathetic when it comes to major issues that affect their lives. If policies regarding the environment, taxes, military spending and health care for example are to reflect public sentiment rather than interest of well-financed lobbyists, they require the attention of ordinary citizens. Improving society, they submitted, requires that schools take this goal seriously: to educate and nurture engaged and informed democratic citizens.

What does it take to make Nigerian students better democratic citizens? To answer this question, Timothy (2003) put it this way: certainly, honesty, responsibility for one's actions and a willingness to help out voluntarily are valuable character traits for good neighbours and citizens but these traits are not inherently about democracy. If democracy is to be effective at improving society, people need to exert power over issues that affect their lives. A democratic citizen's effectiveness is buttressed by the skills needed for civic engagement, for instance, how to work in a group, speak in public, and forge coalitions among varied interests, and protest or petition for change. Opportunities to connect academic knowledge to analysis of social issues are also essential for informed decision-making. In addition, knowledge of democratic processes, of particular issues, and of how to attain and analyze information is important. Democratic citizens should be able to examine the structural causes of social problems and seek solutions to the problem. Moreso, democratic values of tolerance, respect for individual and group identities, and concerns for the greater good are all fundamental ingredients.

Are these basic requirements of sustained democracy imbibed by Nigerian secondary school students? Are the requirements too ambitious? Is it possible for our education programme at this level to be strengthened to prepare citizens for better democratic lifestyle? What then should teachers do to help educate good citizens? How do we guide a transition from rote learning to critical thinking? In all of these questions, citizen participation in democratic governance produces a number of benefits. This varies according to the type of democratic innovation. However, Michels (2011) clearly pointed out that citizen participation is considered a valuable element of democratic citizenship and democratic decision-making. This has positive effects on the quality of democracy as many countries have gained experience with referendums, citizens' forum, citizen's juries, collaborative governance, participatory budgeting and other platform in which citizens have a more direct say.

When citizens are taught the values of democracy, they become active participants in policy making. This helps to ensure that their needs and interest are taken into account in decision-making processes that affect their lives 
at both levels (World Movement for Democracy, 2013) Education in Nigeria at all level seems to be at a standstill.

The decay is massive. From infrastructure to teacher factor, there are obvious problems. Giroux (2011), Hill (2012) and Kincheloe (2007) aptly observed that education at all levels is said to be in a state of crisis, teachers are failing their students, schools are failing the country and public education needs new and creative solutions in order to keep up with time.

\section{Description of the Study}

This is a qualitative study and the purpose of the study was to examine the complexities of Nigerian Social Studies teaching context. The study is designed to answer one fundamental question: how do we teach Nigerian students to think for themselves to become good citizens in a sustainable democracy? Nigerian education system was patterned after the nineteenth century British model. It is more of lecture-based about the three R's and focused more on teaching for memorization and rote learning. This indeed is not an education system that provides learners with opportunities for critical thinking and creativity. It was devoid of questioning and analysis. But building high -level thinking skills is essential for democratic culture. To support this submission, Esu (2010) noted that the Nigerian school curriculum seems to be failing as there is a total disconnection between the school system and the larger society. The curriculum is gradually becoming irrelevant as day passes by. The Nigerian society need a more pragmatic, dynamic, learner and job oriented curriculum capable of enhancing individual and group capacity-building. The individual needs functional education, on the job training, and formal and informal skills development to accomplish tasks and solve problems of capacity-building. The study is also aimed at encouraging Nigerian Social Studies educators to adopt pedagogical practices that enhance students' capacity to function as productive and resourceful democratic citizens in the $21^{\text {st }}$ century. In addition, this study aims at contributing to the scholarly discourse about the role of Social Studies education in the pursuit of guiding the education system in a transition from rote learning to critical thinking which is one determinant of global democratic best practices.

The guiding rationale for undertaking this study is that it is imperative to raise the Social Studies Educator's consciousness to the critical role of the subject the promotion of civic competence. Hence, the knowledge, intellectual processes, and democratic disposition is required of students to be active and engaged participants in public life (NCSS, 1992). A renewed curriculum and redirection of the instructional process that will reflect the $21^{\text {st }}$ century teaching and learning, will help the students to live up to their expectations and role as agents of productive social change and reconstruction (Ndura, 2003, 2004b, 2006c; Ndura \& Makoba, 2006).

\section{Sample of Study}

The sample for the study consisted of 19 participants who are academic staff of the faculties of Education and Social Sciences in the University of Calabar, Nigeria. Five of the participants were female while 14 participants were male. According to Marshall (1996), an appropriate sample size for a qualitative study is one that adequately answer the research question as it might be in single figures for simple questions. Also Sandelowski (1995) noted that a common misconception about sampling in qualitative research is that numbers are unimportant in ensuring the adequacy of a sample strategy. And so determining adequate sample size in qualitative research is ultimately a matter of judgment in evaluating the quality of information collected against the uses to which it will be put, the particular research method and purposeful sampling strategy employed and the research product intended.

All the participants were contacted through the researcher's acquaintance as an academic staff in the same university. Each participant was given a plain sheet of paper with the research question already written for them to write their views about the major research question which is; how do we teach Nigerian students to think for themselves so that they will be good citizens in a sustainable democracy? Each participant responded to the question. While some came and submitted in person to the researcher, others who could not had their responses collected from their offices by the researcher.

After collation of their responses, they were coded to facilitate analysis. The data from the participants were analyzed after collection separately to identify recurrent themes and patterns relevant to Teaching for Democracy in Nigeria: A Paradigm shift.

\section{Findings}

At the end of data collection and coding, four major and recurring patterns and themes emerged for presentation and data analysis: (1) Pedagogy (2) Curriculum reconstruction (3) Entrepreneurial skill development (4) Evaluation. The following discussion will elaborate on each theme individually. 


\section{Pedagogy}

Data were collected and reported as participants' opinions on how to teach Nigerian students to think for themselves to become good citizens in a sustainable democracy. The data is participant's responses to the research question. Their responses are reported according to identified patterns and themes. The coding procedure was by reading through the various responses and taking note of repeated patterns and themes by using different markers for different patterns and themes. The study had only one major research question which is: how do we teach Nigerian students to think for themselves to become good citizens in a sustainable democracy?

It was revealed that most participants have identified a change in the pedagogical process as the surest way forward towards guaranteeing students of Nigeria the ability to think for themselves so that they will be good citizens in a sustainable democracy.

For example, one participant had this to say:

The teacher could use the philosophical method. The role model here is Socrates. This means teaching students to be critical, reflective and enquirers. It is all about putting in their hands the tools they need to find answers for themselves and stimulating them to begin to think more deeply and critically about ideas and arguments. A case in point here is Socrates who taught in a non-dogmatic fashion, subjecting the ideas of students to rigorous critical questioning.

Here is another participant's view: on pedagogy:

The teaching of "values in education" as a core course in our school curriculum is highly recommended. That humanistic education is very essential for preparing young people to be good citizens in a democracy. If a democracy is to work, its citizens must be educated. The students must know how to gather information, distinguish facts from opinions, analyze propaganda, understand many different viewpoints, think for themselves, communicate their opinions clearly and work with others for the common good.

This participant concluded that political education becomes an important aspect of humanistic value education where honesty in playing the game of politics and integrity in holding public office are taught to students.

Furthermore, this participant presented his position in very broad terms about teaching Nigerian students to think for themselves so that they will be good citizens in a sustainable democracy.

To teach Nigerian students to think for themselves in order to become good citizens in a sustainable democracy requires the readiness of a teacher to teach students functional education - education that will make them to become self-reliant and productive in the society.

\section{Curriculum Reconstruction}

Speaking on curriculum reconstruction as a way of teaching students to think for themselves so that they will be good citizens in a sustainable democracy, one participant presented his very broad view by recommending that:

"This of course can be made possible by developing a $21^{\text {st }}$ century functional curriculum".

This implies the curriculum that possesses the in-built capacity to effectively equip the students with requisite skills of life after school that focuses on independent living skills and vocational skills with curriculum emphasis on communication and social skills.

Another participant noted:

There is therefore the need to make learning learner-centered where the teacher becomes guidance to the effort of the learner. This is the gospel of discovery learning, the practical approach to this is by reconstructing the curriculum with greater emphasis on functional curriculum and discovery learning, a method where the role of the teacher will mostly be guidance oriented.

For this participant, the emphasis is in building on citizenship education. And this is how he puts it:

The prospects of citizenship education curriculum are enormous. Among other things, it empowers and equips the students with knowledge of knowing their rights as this teaches them to be strong and reduces their inability to stand firm and defend their rights when the system attempts to cheat them of their privileges. This is what sustainable democracy is all about. These borders on curriculum development, a teaching issue in proper development of a citizen.

\section{Entrepreneurial Skills Development}

Opinions of participants' revealed some agreement among participants that educators have to develop 
entrepreneurial skills among students as this will help promote responsible and productive citizens in a democracy. Here are the views of some participants:

1). Students also can be taught to think for themselves by engaging them in practical work-things they can use their hands to do. This is because during practical work, a child must coordinate between his brain and what he or she is doing with the hands. This is clearly observed in sport where at the spur of the moment, a footballer takes a decision to kick the ball or not. Even in clothes making and other activities that involve practical skills, the same thing applies.

2). They (students) should be armed with entrepreneurial skills as this will ordinarily teach and equip them to be industrious and not to be over-dependent on the system, which is a critical cause of corruption in Nigeria.

3). To be self-reliant, the incorporation of entrepreneurial training into academic curricular is cardinal as this will groom better, responsible and productive students who can contribute to societal growth.

\section{Evaluation}

The researcher's own observation is that a good number of participants advocated for a change in the system of examination. A change in the process of evaluating the students is one sure process of bringing about a radical transition from memorization and rote learning to a more endurable approach to learning. This will better prepare Nigerian students to be able to equip themselves and hence, become good citizens in a democracy. Below are the responses of some participants:

1). I shall adopt both summative and formative evaluation to ascertain if Nigerian students really understand their lessons.

2). Emphasis should be shifted from over-dependence on examination to practical assessment in a reversed order where examination should be $30 \%$ while practical work is based on $70 \%$ of the term work.

3). Group discussion should be encouraged to make our students team players. This skill indeed is lacking among students.

4). Assignment on current issues should be given and if possible each student to a specific topic.

5). Impromptu test with applied questions should be given.

6). Most questions in examinations should be applied.

\section{Discussion and Conclusion}

In Nigeria, we are appreciative of the defective nature of our current school curriculum. The failure to meet up with the realities of the $21^{\text {st }}$ century life after education necessitates a major curriculum restructure. The present curriculum indeed only prepares students for rote learning and memorization. The products of this system lack the basic essentials of democratic citizenship. It is bereft of creativity and critical thinking. This does not encourage analysis and questioning. Any democratic pedagogy must seek to save its citizens from intellectual slavery to be able to restore confidence and independent mindedness. Kincheloe (2007) noted that democratic pedagogy must restore volatility to secondary and post-secondary education the world over. The pedagogy according to Zizek (2009) must further seek to instill the notion of human agency. The volatility and human agency elements in the views of the two authors above have been suppressed due to the crisis in education; and the crisis in Nigeria has manifested in the production of weak graduates at all levels. Our students must be taught that they can fight injustice and so Social Studies teacher Educators in Nigeria must adopt what Zizek (2009) termed circumvention education. This approach encourages educators at all levels to simply teach around the system. They must obviously meet certain mandates imposed on them by the state curriculum and expectations from policy makers.

On the strength of the above, Booth (1977) charged educators to start realizing their role and more importantly the role of education in a truly democratic society.

A brief summary of the findings follows, which centers on the major research question that the study sought to address. It is how will Social Studies educators teach Nigerian students to think for themselves so that they will be good citizens in a sustainable democracy? From the participants' views and responses, it is apparent that there is a big gap in the current trend of education in terms of quality, depth and even the pedagogical approach. Almost all participants demonstrated pervasive awareness of the impact of decade's long focus of teaching for memorization and rote learning in Nigeria. The impact on individual student is great to the extent that the major research question target relates to the means to which educators have the capacity to use their experiences to inspire critical thinking dispositions through their questioning and analysis in the classroom. Letizia (2013) 
suggested that educators must awaken the civic spirit in their students and teach them how to navigate and pressure the system. They must guide students to create newer and higher form of civic participation and involvement.

Furthermore, participants were clear on the need to restructure the curriculum. This therefore calls for quality infusion right from the foundation. No pretence was made in recommending the introduction of functional curriculum. Functional curriculum according to Esu (2010) is a remedial measure to effectively prepare the youth for a perfect future of self-sustenance, and independence. The Nigerian society needs a more pragmatic, dynamic, learner and job-oriented curriculum that should be seen as the "master key" to individual and group capacity building. Because of the narrow nature of the current curriculum, there is a disconnect between the school system and the larger society. Functional and entrepreneurial skills that engender self-awareness, creative-mindedness, positive attitudes, knowledge, value of hard work, questioning skills and analysis are essential for proper adjustment and becoming productive in the society.

The major mandate and characteristics of the paradigm shift in the new direction of teaching among Social Studies teacher educators in Nigeria is to ensure that they produce citizens who support and can defend social justice, criticize public opinion, reject sycophancy and citizens who dedicate their time, talents and resources to fight all forms of oppression, and who ensure the building of tolerance in a multi-ethnic society devoid of fear, tension and suspicion (Ndura, 2007). Social Studies teacher educators must be agents of democratic reproduction of sensitization in their thought, words and actions. All of these must be guided by a national policy on the new curriculum order. This becomes system-level re-engineering and institutional rebranding, according to Obanya (2010). When this is done, it becomes quite easy for Nigerian Social Studies teacher educators to be able to teach Nigerian students to be able to think for themselves to become good citizens in a sustainable democracy.

\section{References}

Arthur, K. E. (1991). Teaching and Learning Elementary Social Studies. London: Allyn and Bacon.

Blake, N., Smith, R., \& Standish, P. (1998). The Universities we need: Eduction after dearing. London: Kogan Page.

Dewey, J. (1941). Education Today. London: George Allen and Unwin

Esu, A. E. O. (2010). Functionality of Curriculum in Nigeria. A paper presented at a seminar of the World Council for Curriculum and Instruction, Enugu Chapter held at the University of Nigeria Nsukka in October 2009.

Gana, T., \& Omelle, Y. B. (2003). Democratic Rebirth in Nigeria: Volumne One from 1999-2003. New Jercey: AfricaRUs Multimedia.

Giroux, H. (2011). On Critical Pedagogy. New York: Continuum.

Hill, D. (2012). Immiseration Capitalism, Activism and Education: "Resistance, revolt and revenge". Journal for Critical Education Policy Studies, 10, 1-34.

Kahne, J., \& Westheimer, J. (2003). Teaching for Democracy: What schools need to do. Phi Delta Kappan, 85(1), 40, 57-66.

Kincheleo, J. (2004). Critical Pedagogy in the twenty fisrt century: Evolution for survival. In P. Mclaren, \& J. Kincheleo (Eds.), Critical Pedagogy, where are we now? NY: Peter Lang.

Letizia, A. J. (2013). Teaching Democracy and Revolution. Retrieved September 14, 2013, from http://philosophersforchange.org/2013/06/04/teaching-democracy-and-revolution

Marshal, M. N. (1996). Sampling for qualitative research. London: oxford university press. http://dx.doi.org/10.1177/104973239600600102

Michels, A. (2011). Innovations in democratic governance: How does citizens participateion contribute to a better democracy? International Review of Administrative Science, 77(2), 275-293. http://dx.doi.org/10.1177/0020852311399851

National Council for the Social Studies. (1994). Expectations of Excellence: Curriculum Standards for Social Studies. Washington, D. C.: NCSS.

Ndura, E. (2003). Peaceful Conflict Resolution: A prerequisite for reconstruction in Burundi, Africa. In E. E Uwazie (Ed.), Conflict resolution and peace education in Africa (pp. 151-160). Lanham, MD: Lexington Books. 
Ndura, E. (2004b). Building a foundation for sustainable peace in Burundi: A transformative Multicultural education framework. A paper presented at the annual conference of the peace and justice studies Association, held in Sanfrancisco, Californiaa on the $14^{\text {th }}-17^{\text {th }}$ October, 2004.

Ndura, E. (2006). Transcending the majority rights and minority protection dichotomy through multicultural reflective citizenship in Africa Great Lakes region. International Education, 17, 195-205.

Ndura, E., \& Makoba, J. W. (2006). Transforming Society and fostering peace through education in Burundi and Rwanda. A paper presented at the Biannual conference of the International peace Research Association (IPRA) held in Canada on the $29^{\text {th }}$ June- $3^{\text {rd }}$ July, 2006.

Obanya, P. (2010). System Re-engineering and Institutional rebranding for a world class university: The Nigerian perspective. $4^{\text {th }}$ Annual Lecture of Professor Grace Mbipom Foundation delivered at the University of Calabar Hotel conference hall on the $1^{\text {st }}$ June 2010.

Petters, S. W. (1997). Strategies for Environmental Resources Management. In K. M. O. Etta (Ed.), Nigeria's Ultimate Goals: The journey so far. Calabar: University of Calabar Press.

Portelli, J. P., \& Solomon, R. P. (2001). The erosion of democracy in education. Calgary, A. B.: Detselig Enterprises Ltd.

Sandelowski, M. (1995). Sample size in qualitative research. Retrieved from http://www.ncbi.nlm.nih.gov/pubmed.7899572

Timothy, J. S. (2003). Creating the Space for civic dialogue. Phi Delta Kappan, 85(1), 38.

Ubi, O. A. (2000). Ethnicity and Nation Building in Nigeria. In E. U. Okon (Ed.), Civil Society and Consolidation of Democracy in Nigeria. Calabar: Clear-Line Publishers.

Wood, G. H. (1990). Teaching for Democracy. Virginia: Informed Curriculum Leadership.

World Movement for democracy. (2013). Making democracy work. Retrieved from http:/www.wmd.org/assemblies/sixth-assembly/workshops/makkingdemocracy-work/how-ennsure-citizen

Zizek, S. (2009). First as Tragedy, then as Farce. New York, NY: Verso Press.

\section{Copyrights}

Copyright for this article is retained by the author(s), with first publication rights granted to the journal.

This is an open-access article distributed under the terms and conditions of the Creative Commons Attribution license (http://creativecommons.org/licenses/by/3.0/). 